\title{
Silent pirates: Anolis sagrei Duméril \& Bibron, 1837 (Squamata, Dactyloidae) taking over Panama City, Panama
}

\author{
Abel Batista ${ }^{1,2,3}$, Marcos Ponce $^{2}$, Orlando Garcés ${ }^{3}$, Elliot Lassiter $^{4}$, Madian Miranda ${ }^{3}$ \\ 1 Universidad Autónoma de Chiriquí, Vicerrectoría de investigación y Postgrado, Museo de Historia Natural, Ciudad Universitaria El Cabrero \\ David, Chiriquí, 427, Panamá. 2 Museo Herpetológico de Chiriquí, David, Chiriquí, 426-01459, Panamá. 3 Los Naturalistas, David, Chiriquí, \\ 426-01459, Panamá. 4 Smithsonian National Zoological Park, 3001 Connecticut Ave. NW, Washington, DC 20008, USA. \\ Corresponding author: Abel Batista, abelbatista@hotmail.com
}

\begin{abstract}
Anolis sagrei Duméril \& Bibron, 1837 is one of the most widespread reptiles in the world, having colonized more than 15 countries on 2 continents. It inhabits open areas and is commonly found around big cities. We noticed the presence of an unreported, nonnative population in Panama City, Panama, which has been established since at least 5 years. We report Anolis sagrei for the first time in Panama based on collected specimens. We argue that the species is currently abundant in some areas and it could be a threat for native species.
\end{abstract}

\section{Keywords}

Alien species, invasive species, new country record.

Academic editor: Rafael de Fraga | Received 28 February 2019 | Accepted 7 May 2019 | Published 7 June 2019

Citation: Batista A, Ponce M, Garcés O, Lassiter E, Miranda M (2019) Silent pirates: Anolis sagrei Duméril \& Bibron, 1837 (Squamata, Dactyloidae) taking over Panama City, Panama. Check List 15 (3): 455-459. https://doi.org/10.15560/15.3.455

\section{Introduction}

Panama City has a long history of transit and has played an important role in the worldwide commercial trade (Osorio 2016, Parker 2009). Nowadays, there are no pirates, but the continued traffic through the Panama Canal (PC) has provided a means of transport and colonization of invasive flora and marine fauna in and around the canal (Hammond 1998, Ros et al. 2014). However, there is a lack of scientific evidence that terrestrial fauna have colonized the country through the PC (Crawford et al. 2011). Although, there are colonization records of exotic frogs and nocturnal geckos into Panama, hypothesized to be attributable to the PC ship traffic (Crawford et al. 2011, Ibáñez and Rand 1990, Smith and Grant 1961), but no diurnal lizards have been documented until now.
Here we report for the first time the colonization of Panama by an alien lizard, Anolis sagrei Duméril \& Bibron, 1837 which may have been established for as long as a decade.

Anolis sagrei is one of the most widespread anoline lizards in the world. It has been recorded from 2 continents (America and Asia) and more than 15 insular and continental countries in the Americas (Amador et al. 2017, Lee 1996, Norval et al. 2012, Tan and Lim 2012). The species is native to Cuba and the surrounding islands (Williams 1969), and was recorded for the first time outside its natural distribution in Florida Keys, United States (Garman 1887). In Mesoamerica, the species has been reported in Mexico, Belize, and Costa Rica (Köhler 2008, Lee 1996). This species is well adapted to urban areas, and the biological requirements are very 


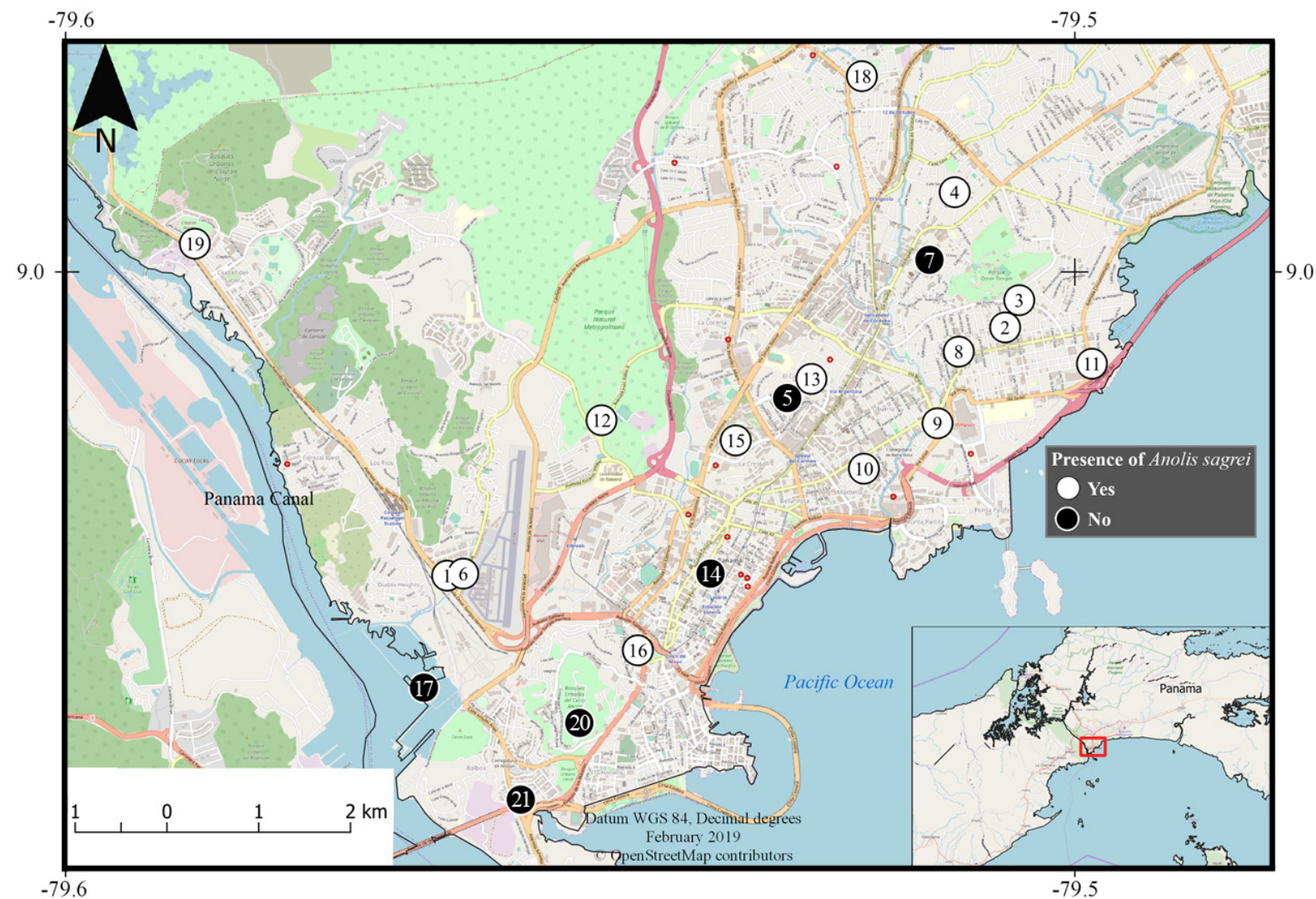

Figure 1. Distributional map of Anolis sagrei in Panama City, Panama. Open circles indicate presence and close circles absence of $A$. sagrei. Numbers correspond to those localities shown in Table 1.

low. Therefore, there are populations living in small patches of bushes in gardens around big cities (Amador et al. 2017). Anolis sagrei has fast reproductive cycle and ontogenetic development, females can lay an egg every 10 days, and one-month old juveniles may be reproductively mature (Lee et al. 1989). Due to these fast reproductive cycles, colonizing new and urban areas should not be difficult for this species (Amador et al. 2017, Tan and Lim 2012, Williams 1969). Additionally, it can easily adapt to new environments to feed and avoid predators (Kenny et al. 2017, Lapiedra et al. 2018, Schoener et al. 2017). Herein, we report the presence of $A$. sagrei for the first time in Panama City, Panama, with photographic evidence and collected specimens, and discuss the potential impact of this invasive lizard on native species.

\section{Methods}

On 26 March 2018, we received a photograph from the Director of the Audubon Society Panama, R. Miro, of an anole near the Panama Railway Company at Albrook (Fig. $1 ; 08.9699^{\circ} \mathrm{N}, 079.5622^{\circ} \mathrm{W}$ ). The photo showed a courting pair of anoles on the border of a plantation of ornamental ferns (Fig. 2A). A month later, we received another photo from an ornithologist, R. Jordan, of an anole from 50th Street, downtown Panama City $\left(08.9805^{\circ} \mathrm{N}, 079.5209^{\circ} \mathrm{W}\right)$, one of the most used roads in the city (Figs 1,2). We went to those locations and confirmed the presence of the non-native Anolis sagrei.
Table 1. Geographic coordinates used in this study. Localities correspond to those shown on Figure 1, with presence or absence of Anolis sagrei, for the surveyed areas in Panama City.

\begin{tabular}{llccl}
\hline \multirow{2}{*}{$\#$} & Locality & \multicolumn{2}{c}{ Coordinates } & \multirow{2}{*}{ Presence } \\
\cline { 3 - 4 } & & ${ }^{\circ} \mathbf{N}$ & ${ }^{\circ} \mathbf{W}$ & \\
\hline 1 & Albrook & 08.9699 & 079.5622 & Yes \\
2 & 73th Street & 08.9945 & 079.5069 & Yes \\
3 & Parque Recreativo Omar & 08.9972 & 079.5055 & Yes \\
4 & Hato Pintado & 09.0079 & 079.5119 & Yes \\
5 & 53th Street & 08.9875 & 079.5285 & No \\
6 & UDELAS & 08.9701 & 079.5606 & Yes \\
7 & 66th Street & 09.0012 & 079.5144 & No \\
8 & 67th E Street & 08.9921 & 079.5115 & Yes \\
9 & 50th Street & 08.9850 & 079.5136 & Yes \\
10 & 50th Street & 08.9805 & 079.5209 & Yes \\
11 & Around Atlapa CC & 08.9909 & 079.4983 & Yes \\
12 & Metropolitan Park & 08.9853 & 079.5469 & Yes \\
13 & Andres Bello Park & 08.9894 & 079.5261 & Yes \\
14 & Fransisco A. Paredes Park & 08.9701 & 079.5361 & No \\
15 & Univerity of Panama & 08.9833 & 079.5336 & Yes \\
16 & STRI, Tupper, 5 de Mayo & 08.9625 & 079.5433 & Yes \\
17 & Balboa Port & 08.9588 & 079.5645 & No \\
18 & Guayacanes Forest Park & 09.0194 & 079.5211 & Yes \\
19 & Clayton & 09.0028 & 079.5872 & Yes \\
20 & Cerro Ancón & 08.9553 & 079.5491 & No \\
21 & Balboa & 08.9477 & 079.5549 & No \\
\hline & & & &
\end{tabular}

The only vegetation available to the lizards were small patches of gardens and scattered trees (Fig. 2).

We set 14 transects along the city, $100 \mathrm{~m}$ long each, and used active visual search to find anoles $(5 \mathrm{~m} / \mathrm{min}$.). All surveyed areas are within Panama City and are 

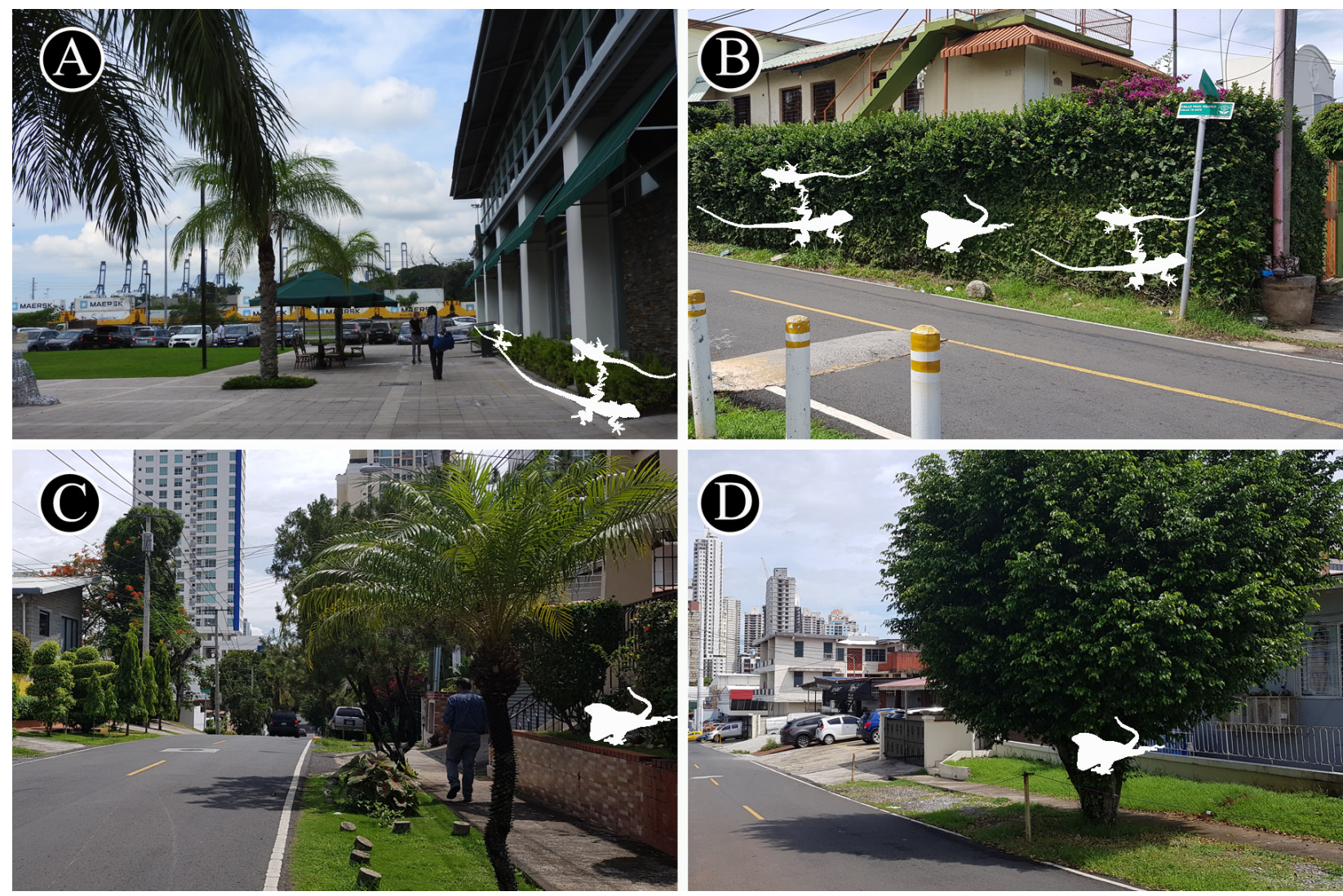

Figure 2. Habitat of Anolis sagrei in Panama City, Panama. A. Deli Gourmet Restaurant, Albrook, Balboa Port and Panama Canal Railway Company at background; B-D. Around $50^{\text {th }}$ Street, downtown Panama City. White lizard images correspond to places where we found specimens.

surrounded by high traffic roads and buildings. All the specimens found were georeferenced using the WGS 1984 datum. A distribution map was created using QGIS (QGIS 2018) with an OSM layer (OSM contributors 2015). Collected specimens were euthanized with a pericardial injection of a euthanasia drug (T61), fixed using a solution of formalin (36\%) and ethanol (94\%, 1:200), stored in $70 \%$ ethanol, and deposited at the Museo Herpetológico de Chiriquí ( $\mathrm{MHCH}$ ), at the Universidad Autónoma de Chiriquí. All figures have been digitally improved and combined using Adobe Photoshop CS6. We described body colors based on photos of collected specimens in life. Snout-vent length and tail length measurements were taken using digital calipers. Terminology for morphometrics and pholidosis follows Köhler (2014). Collecting permit (SE/A-33-18) was provided by UNARGEN-Ministerio de Ambiente, Panama.

\section{Results}

Vouchered record. Panama, Panama province: Panama City: 67 th Street East $\left(08.9921^{\circ} \mathrm{N}, 079.5115^{\circ} \mathrm{W}\right)$, coll. by A. Batista, M. Ponce, M. Miranda, 22 May 2018 (MHCH 3223, 1 male).

This is the first record for the species in Panama.

Additional records. We found 25 specimens, 7 females $(\mathrm{SVL}=50.67 \mathrm{~mm} \pm 13.4, n=6), 10$ males $(\mathrm{SVL}=42.67$ $\mathrm{mm} \pm 4.72, n=6), 1$ unmeasured juvenile, and 7 unsexed adults. In Albrook, we found 6 individuals basking in the border of planters (Fig. 2A). In a 30 min search at 50th Street (Fig. 2B-D), we found 11 individuals (4 males, 4 females, and 3 young). We collected one of them ( $\mathrm{MHCH}$ 3223; Fig. 3) to confirm species identification. We found A. sagrei in 8 out of 14 transects, with an average of 1.6 individuals per transect. The minimum local range of $A$. sagrei in Panama City was estimated to be $28 \mathrm{~km}^{2}$.

Identification. We identified A. sagrei based on the set of diagnostic characters proposed by Köhler (2008). This is composed of compressed tail, orange to red dewlap with a yellow margin and scales and enlarged post-anals. Sebastian Lotzkat confirmed the species identification.

\section{Discussion}

The origin of $A$. sagrei in Panama remains unknown, but 2 hypotheses are most likely: (1) via shipments arriving to the Port of Balboa, or (2) as captive individuals released around the city. Containers arriving at Balboa would be the most probable source of origin. However, as the A. sagrei occurs in the Caribbean islands and most ships arrive come from the Pacific, we can dismiss this possibility. Instead, containers carried by the trans-isthmian train coming from Cristobal, a Caribbean port in Colón, and subsequently taken to Balboa could be an option. One of the locations reported here is very close to the Port of Balboa, and one can even 


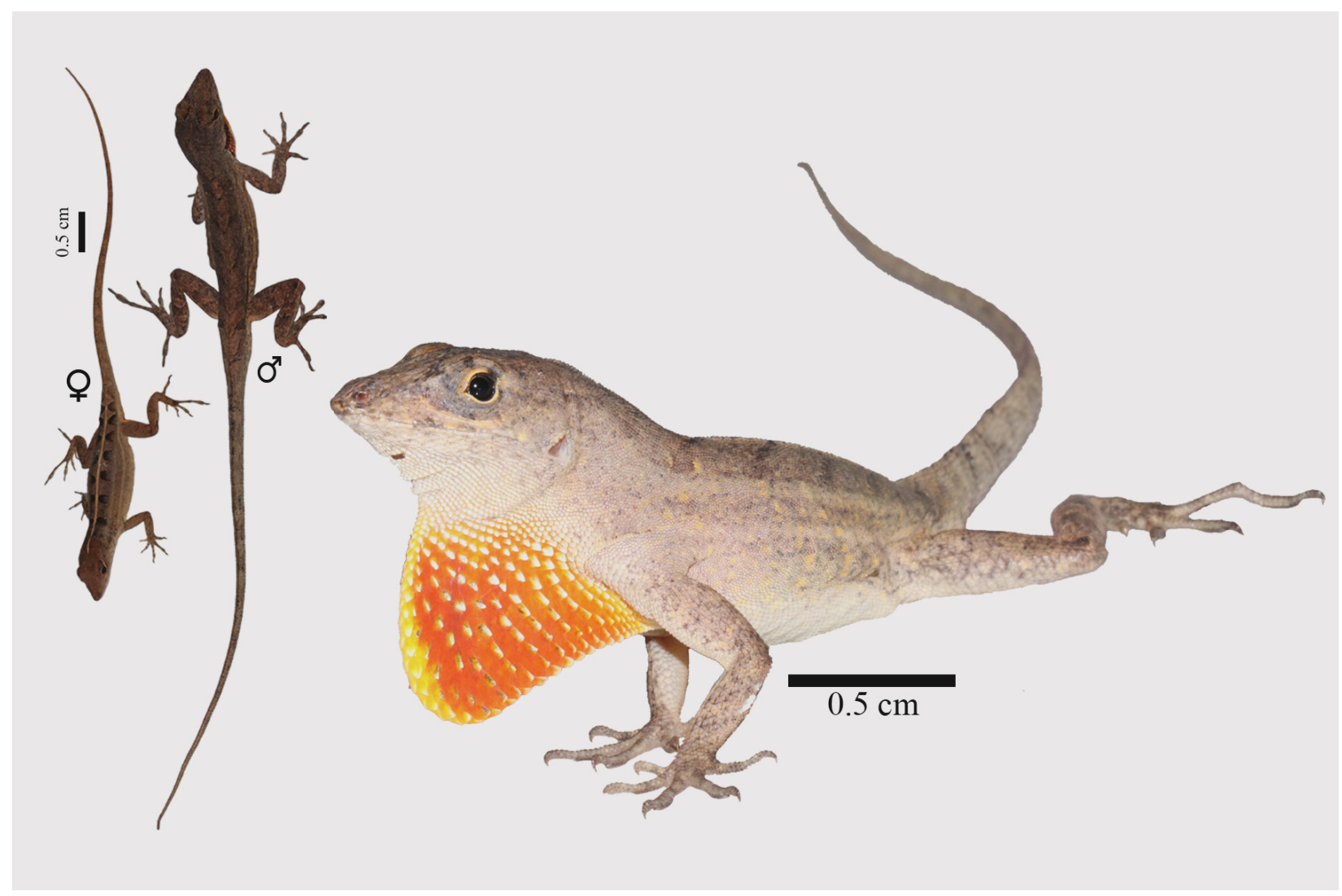

Figure 3. Two individual of Anolis sagrei found around $50^{\text {th }}$ Street, downtown Panama City. Left: female and male (MHCH 3223), right: male (MHCH 3223).

see the trans-isthmian train from it (Fig. 2A). Captive released individuals around the city could also be a possible source of invasion. However, reptiles as pets are not common among Panamanians, and support for this hypothesis is weak.

Panama City is surrounded by natural protected areas, such as the Metropolitan Natural Park, which is very close to the locations in Albrook where we have found A. sagrei. The species mainly occupies open areas, it is highly territorial, and it can ecologically displace native species (Williams 1969). It is relatively well adapted to find food and avoid predators at newly colonized habitats (Schoener et al. 2017). Therefore, its capacity to displace other native species may be high. Native species such as Gonatodes albogularis (Duméril \& Bibron, 1836) and Anolis gaigei (Ruthven, 1916), which are common around forest edges at the Metropolitan Natural Park and Cerro Ancón, could potentially be displaced by $A$. sagrei. Another concern is the species' potential of population growth at high densities of up to 0.97 lizards per $\mathrm{m}^{2}$ (Schoener and Schoener 1980), contrary to Mesoamerican mainland species, for which densities do not exceed 0.14 lizards per $\mathrm{m}^{2}$ (Sexton et al. 1963, Heatwole and Sexton 1966). We currently do not have evidence of native species displacement, and $A$. sagrei probably does not have any competitors, as native anoline lizards usually occupy habitats on the outskirts of the city. However, the presence of A. sagrei in Panama City is a potential threat to local species because
A. sagrei could eventually share the same habitats along forest edges and, even more importantly, possibly transmit diseases or parasites to native species (Goldberg and Bursey 2000, Doan et al. 2019).

Anolis sagrei has a tremendous colonization capacity. It has recolonized $80 \%$ of the 50 islands in the Bahamas, 19 months after the islands being directly affected by the Hurricane Floyd (Schoener et al. 2001). This species could have become established in Panama at least 5 years ago and it was possibly misidentified as $A$. tropidogaster (Prof. Cambra pers. comm.). Additionally, the species may have been unnoticed in Panama City, because it can easily be confused with the native $A$. gaigei (C. Jaramillo pers. comm.). Distinguishing the species mainly relies on the smaller dewlap with a yellow margin (Köhler et al. 2012: fig. 3C, D), and compressed tail in A. sagrei (Köhler 2008; Köhler et al. 2012: figs 4F, 7C, D). Anolis sagrei also often occupies open and urbanized areas and shows behavioral repertoires that are not observed in $A$. gaigei, such as aggressive responses of males to approaching males or even females. Anolis gaigei is more secretive and it is mainly found in low semideciduous forests and bushy savannahs, usually on trees or fences enclosing cattle pastures. Estimates of population densities and long-term monitoring are required to refine the distribution of $A$. sagrei in Panama, as well as to assess dispersal rates and colonization routes. These studies should focus on the potential invasion of nonanthropogenic areas around Panama City. 


\section{Acknowledgements}

We thank R. Miró, R. Jordán, R. Cambra, E. Leiva, and the WhatsApp group Reptiles of Panama for providing records of presence. We also thank D. Miranda for help in finding lizards, and to R. de Fraga, E. Hofmann, and P. de Oliveira Calixto for insightful comments on an earlier draft of the manuscript.

\section{Authors' Contributions}

$\mathrm{AB}, \mathrm{MP}, \mathrm{OG}$ and $\mathrm{MM}$ collected the data. $\mathrm{AB}$ and $\mathrm{MP}$ examined the specimens. AB and MM took the photographs and arranged table and figures. OG made transects and collected additional information. $\mathrm{AB}$ and $\mathrm{MM}$ wrote the text.

\section{References}

Amador L, Ayala-Varela F, Nárvaez AE, Cruz K, Torres-Carvajal O (2017) First record of the invasive Brown Anole, Anolis sagrei Duméril \& Bibron, 1837 (Squamata: Iguanidae: Dactyloinae), in South America. Check List 13 (2): 2083. https://doi.org/10.155 $60 / 13.3 .2083$

Crawford AJ, Sucre S, Alonso R, Ibáñez DR (2011) DNA barcoding identifies a third invasive species of Eleutherodactylus (Anura: Eleutherodactylidae) in Panama City, Panama. Zootaxa 2890: 65-67. https://doi.org/10.11646/zootaxa.2890.1.6

Doan, TM, Devlin, BG, Greene, KC (2019) Malaria infection is lower in invasive anoles than native anoles in central Florida, USA. Journal of Herpetology 53 (1): 22-26. https://doi.org/10.1670/18-056

Garman S (1887) On West Indian Iguanidae and on West Indian Scincidae in the collection of the Museum of Comparative Zoology at Cambridge, Mass., U.S.A. Bulletin of the Essex Institute 19 (1): 25-53.

Goldberg SR, Bursey CR (2000) Transport of helminths to Hawai via the brown anole, Anolis sagrei (Polychrotidae). Journal of Parasitology 86 (4): 750-755. https://doi.org/10.1645/00223395(2000)086[0750:TOHTHV]2.0.CO;2

Hammond BW (1998) Saccharum spontaneum (Gramineae) in Panama: the physiology and ecology of invasion. Journal of Sustainable Forestry 8 (3-4): 23-38. https://doi.org/10.1300/J091v 08n03 03

Heatwole H, Sexton OJ (1966) Herpetofaunal comparisons between two climatic zones in Panama. American Midland Naturalist 75 (1): 45-60. https://doi.org/10.2307/2423482

Ibáñez DR, Rand S (1990) Eleutherodactylus johnstonei. Herpetological Review 21: 37

Kenny HV, Wright AN, Piovia-Scott J, Yang LH, Spiller DA, Schoener TW (2017) Marine subsidies change short-term foraging activity and habitat utilization of terrestrial lizards. Ecology and Evolution 7 (24): 10701-10709. https://doi.org/10.1002/ece3.3560

Köhler G (2008) Reptiles of Central America. 2nd edition. Herpeton Verlag, Offenbach Germany, 400 pp.

Köhler, G, Batista, A, Vesely, M, Ponce, M, Carrizo, A, Lotzkat, S
(2012) Evidence for the recognition of two species of Anolis formerly referred to as A. tropidogaster (Squamata: Dactyloidae). Zootaxa 3348 (1): 1-23. https://doi.org/10.11646/zootaxa.3348.1.1

Koehler G (2014) Characters of external morphology used in Anolis taxonomy - definition of terms, advice on usage, and illustrated examples. Zootaxa 3774 (3): 201-257. https://doi.org/10.11646/ zootaxa.3774.3.1

Lapiedra O, Schoener TW, Leal M, Losos JB, Kolbe JJ (2018) Predator-driven natural selection on risk-taking behavior in anole lizards. Science 360 (6392): 1017-1020. https://doi.org/10.1126/ science.aap9289

Lee JC (1996) The Amphibians and Reptiles of the Yucatan Peninsula. Cornell University Press, Ithaca, New York, 500 pp.

Lee JC, Clayton D, Eisenstein S, Perez I (1989) The Reproductive Cycle of Anolis sagrei in Southern Florida. Copeia 1989 (4): 930-937. https://doi.org/10.1645/12-30.1

Norval G, Goldberg SR, Mao J-J (2012) The reproductive cycle of the brown anole (Anolis sagrei), an invasive lizard species in Taiwan. Russian Journal of Herpetology 19 (1): 75-81.

OSM contributors. (2015) Open Street Map, https://www.openstreet map.org/\#map=8/8.420/-80.113. https://planet.openstreetmap.org. Accessed on: 2019-02-25.

Osorio K (2016) Génesis de una propiedad del Patrimonio Mundial: El Mar del Sur y el "Sitio Arqueológico de Panama Viejo y Distrito Histórico de Panama”. http://openarchive.icomos.org/1806/. Accessed on: 2017-11-25.

Parker M (2009) Panama Fever: The Epic Story of the Building of the Panama Canal. Anchor Books, New York, 531 pp.

QGIS DT (2018) QGIS Geographic Information System. Version 3.2.1. Open Source Geospatial Foundation Project, QGIS Development Team. https:/qgis.org/en/site/.

Ros M, Ashton GV, Lacerda MB, Carlton JT, Vazquez-Luis M, Guerra-Garcia JM, Ruiz GM (2014) The Panama Canal and the transoceanic dispersal of marine invertebrates: evaluation of the introduced amphipod Paracaprella pusilla Mayer, 1890 in the Pacific Ocean. Marine Environmental Research 99: 204-211. https://doi.org/10.1016/j.marenvres.2014.07.001

Schoener TW, Kolbe JJ, Leal M, Losos JB, Spiller DA (2017) A multigenerational field experiment on eco-evolutionary dynamics of the influential lizard Anolis sagrei: a mid-term report. Copeia 105: 543-549. https://doi.org/10.1643/ce-16-549

Schoener TW, Schoener A (1980) Densities, sex ratios, and population structure in four species of Bahamian Anolis lizards. The Journal of Animal Ecology 49 (1): 19-53. https://doi.org/10.2307/4276

Schoener TW, Spiller DA, Losos JB (2001) Natural restoration of the species-area relation for a lizard after a hurricane. Science 294 (1): 1525-1528. https://doi.org/10.1126/science.1064396

Sexton OJ, Heatwole HF, Meseth EH (1963) Seasonal population changes in the lizard, Anolis limifrons, in Panama. American Midland Naturalist 69 (1): 482-491. https://doi.org/10.2307/2422924

Smith HM, Grant C (1961) The Mourning Gecko in the Americas. Herpetologica 17 (1): 68.

Tan HH, Lim KP (2012) Recent Introduction of the Brown Anole Norops sagrei (Reptilia: Squamata: Dactyloidae) to Singapore. Nature in Singapore 2012 (5): 359-362.

Williams EE (1969) The ecology of colonization as seen in the zoogeography of anoline lizards on small islands. The Quarterly Review of Biology 44 (4): 345-389. 